\title{
Jonathan Swift's Registers in A Modest Proposal
}

\author{
LADAPO, Folorunso Oladeji (Ph.D.) \\ Department of Languages and Literary Studies, Adeleke University,Ede, Osun State, Nigeria
}

\begin{abstract}
This paper attempts to make a stylistic analysis of Jonathan Swift's registers in A Modest Proposal. In literary writing, a writer chooses his words with care, making sure that the words fit properly into the discourse. This proper choice and use of words is 'diction'. In carrying out the subtle task of ensuring proper diction, most writers often search for relevant technical terms appropriate to their discourse with a view to achieving realism. Thus, a writer becomes a roving camera, delving into other disciplines so as to achieve this realism. Using the Communication Accommodation Theory (CAT), it is discovered that Swift achieves profound literary realism in A Modest Proposalthrough appropriate diction and navigation in various registers to the extent that one is prone to conclude that Swift's profession is multi-dimensional in nature, a positive chameleon in terms of his calling; indeed a literary rainbow with several appearances. Though a single human being, he is discovered to be a man of many diverse parts through his diction that cuts across nine professions/disciplines. He is a literary writer who delves into various professions simultaneously to have an organic unity which natural novels have in common. This paper therefore submits that A Modest Proposal is a literary work that exemplifies convergence adjustment aspect of the Communication Accommodating Theory of Howard Giles as a means of effective communication in literary writing.
\end{abstract}

Keywords:Communication Accommodation Theory, Register, Profession, Diction

DOI: $10.7176 /$ RHSS/11-16-04

Publication date:August $31^{\text {st }} 2021$

\section{Introduction}

The linguistic theory upon which this paper is anchored is Communication Accommodation Theory (CAT) which is a "comprehensive conceptual framework describing the ways in which people adjust their communication behaviours during social interactions, their motivations for doing so and the social consequences" (Kate Muir, Adam Joinson, Rachel Cotterill \& Nigal Dawdney, alluding to Giles, Coupland, \& Coupland, 1991). It is a theory developed by Howard Giles, a Professor of Communication at the University of California in 1971. (www.businesstopia.net>communication)(accessed at 10.58am on 26/3/21).

It is the argument of CAT that "during conversation, each speaker makes ongoing evaluations about their partner" and make "adjustments to their communication behaviours" (ibid). Such adjustments can be that of "convergence" or "divergence". 'Convergence' in communication explains the situation when people change their communication behavior to be "similar to others" while 'divergence' explains the situation when people change their communication behavior to further promote differences in communicative acts. In summary, convergence in communication is "to gain social approval" while "divergence in communication is "to emphasize or increase social distance" (ibid).

In this paper, Jonathan Swift's A Modest Proposalis being analyzed through the convergence form of Communication Accommodation Theory (CAT) because the satirist seems to have gained the social approval of the audience of the 18th Century as well as subsequent centuries. The chameleonic nature of Swift is a positive one because he was able to synchronize the various registers of the disciplines which his message involves in a linguistically beautiful manner that makes the pamphlet worth of being studied at most times.

Who is Jonathan Swift?

In as much as a writer's background usually affects his/her writing, it is appropriate to examine briefly the background of Jonathan Swift. According to Dent (1967) and www.poetryfoundation.org>poets, Swift was a great English satirist, born in Dublin, Ireland, into a poor English family. He never knew his father because the father died before he was born. He went to Trinity College, Dublin where he obtained a degree. Much about the character and the social context of Swift's life is evident from his published works, especially 'A Journal to Stella' which is a series of letters. There is enough evidence that Swift disliked Irish culture and considered residence in Ireland as banishment. Nonetheless, he was interested in Irish affairs and gained extraordinary popularity there with his 'Drapier's Letters' (1724) which was directed against English policy in Ireland. Most of his works are classifiable as 'satire' and reveal Swift's anger that men's action should fall below those of creatures of reason. It is pertinent to note that his poor parentage, dislike for Irishand English policies in Ireland greatly influenced his style of writing in A Modest Proposal. His other literary works included A Tale of a Tub, The Battle of the Books and Gulliver's Travels. 
Jonathan Swift as a Positive Literary Chameleon in a Modest Proposal

Swift was known as a literary man highly reputed in the field of literature but a stylistic study of the registers of $A$ Modest Proposal reveals that, in terms of his calling (i.e. profession, occupation, special duty), he was a positive chameleon; indeed a literary rainbow with at least nine different callings to the extent that one is impressed about the sterling stuff he was made of. The questions that agitate one's mind therefore are multifarious and can be summed up as:

$\begin{array}{ll}\text { was he a mere literary man? } & \text { a caterer (or hotelier)? } \\ \text { a sociologist? } & \text { an animal scientist? } \\ \text { an economist? } & \text { or an agriculturist? } \\ \text { or a pamphleteer? } & \text { a mathematician? }\end{array}$

He seemed to be an embodiment of them all. This claim is substantiated by the overall content of the prose passage which has features of registers related to the professions indicated above. In as much as this paper centres on registers, it is apt at this juncture to briefly dwell on it.

\section{Registers}

Bullon (2008, p.1380) explains that 'register' is a technical word in language and styles which means "the words, style and grammar used by speakers and writers in a particular situation or in a particular type of writing". It is the "functional varieties" of a language Ghadessy(1993, p.1). It is a theory that tries to open up "the general principles which govern the ways the language we speak or write varies according to the type of situation" (ibid, p.9). In dealing with register analysis, it is instructive for scholars to know the field, mode and tenor of the writing/speech. It is also instructive to know that "register" is the "clustering of semantic features" (ibid, p.10) as well as a "configuration of semantic resources that the member of a culture typically associates with a situation type" (Halliday, quoted by Ghadessey (1993, p.10).

The knowledge of different "registers" is very important for any creative writer due to the fact that every creative writer is expected to use appropriate registers in the conveyance and portrayal of his/her message to the intended audience in the indeterminate outerspace that is boubdless in outreach. This power of language enables a writer to effectively express his ideas in a way that is naturally like any one in each of the professions that the essay, novel, play or poetry deals with. If the registers are not appropriate, there will be obvious (or hidden) linguistic gaps and inadequacies, such as will make the work of art to be watery, dull, unappealing and unattractive. The importance of good registers made Ghadessey to indicate that the "command over a wide range of registers is a major implement of social power (1993:18) and that "the entry to specialized fields of knowledge, particularly to prestigious ones like science and technology, depends materially on commanding the appropriate register" (ibid).

\section{Analysis of Registers in A Modest Proposal}

The prose passage consists of ten pages which amount to three hundred and eighty three lines with each line having an average of eight and a half words. This gives a total of three thousand, two hundred and fifty-five words. It is represented in figures below:

383 Lines X $81 \frac{1}{2}$ words $=3,255$ words.

Out of the total number of words, we have the following divisions of words per profession:

$\begin{array}{lll}\text { Economics } & - & \pm 160 \\ \text { Animal Science } & - & \pm 128 \\ \text { Agriculture } & - & \pm 129 \\ \text { Catering } & - & \pm 139 \\ \text { Sociology } & - & \pm 50 \% \text { of the total number of words. } \\ \text { Politics } & - & \pm 20 \% \text { of the total number of words. } \\ \text { Mathematics } & - & \pm 559 \\ \text { Pamphleteering } & - & \text { All the } 3,255 \text { words } \\ \text { Creative Writing } & - & \text { All the } 3,255 \text { words }\end{array}$

It should be noted that the figures are mutually inclusive; elements of one group may be found in others. Be that as it may, the figures fairly represent the various professions.

\section{Pamphleteering}

Swift used registers of pamphleteering. This is because his A Modest Proposal is a 'small paper ... on a question of current interest'. The passage is of ten pages which by any standard is a pamphlet. Yet, it carries a full-fledge message which can be described as a 'horrible but masterly piece of irony that explains the poor conditions of living in Ireland' of Swift's time. Indeed a time of oppression of the poor by the rich. As a result of the situation, the pamphlet is aimed at "preventing the children of poor people in Ireland from being a burden 
to their parents or country, and for making them beneficial to the public." This aim was carried out by Swift throughout the proposal and whether he was sincere about the ironic tract or not is a matter of debate elsewhere. Suffice to say that for the whole (about) three thousand, two hundred and fifty-five words of the tract, Swift used the register of pamphleteering in presenting his 'Modest Proposal' to the public.

Sociology

If a sociologist is an expert in the science of the nature and growth of society and social behavior (Turnbull, Joanna, 2010,p1414), then, Swift used registers of sociologists. For about 50\% (fifty percent) of the pamphlet, he concerned himself with the social menace and 'melancholy object' which the beggar of the female sex, followed by three, four, or six children, all in rags and importuning for alms constituted in Ireland. He chose the registers of a sociologist, and felt very concerned with the way "those mothers ... are forced to employ all their time in strolling to beg sustenance for their infants: who, as they grow up, either turn thieves for want of work, or leave their dear native country to fight". He also wished, through his pamphlet, to solve the disastrous problem of "those voluntary abortions, and the horrid practice of women murdering their bastard children ... sacrificing the poor innocent babes" (p.3). The pamphlet is therefore a sociological one which appears to have been carefully prepared by a concerned sociologist.

Economics

While one sees $A$ Modest Proposal as one that aims at settling the social problems of Ireland, one also needs to see it as being a laudable economic programme beneficial to both the rich and the poor, though in a fierce ironic manner. Swift, in the work, appears to be presenting a carefully prepared feasibility study on a programme that is aimed at salvaging an ailing economy. In fact, his style appears to be that of a contemporary holder of a doctoral degree in Economics from the London School of Economics. Apart from mutually inclusive words, about one hundred and sixty other words appear to be related to economics and he used the words to succinctly put his economic 'proposal'. Such words and phrases include:

$\begin{array}{lll}\text { laws } & \text { circulate } & \text { foreign luxury } \\ \text { price } & \text { nation's stock } & \text { be sold somewhat cheaper } \\ \text { trade } & \text { industry } & \text { important customers } \\ \text { offer } & \text { receipts } & \text { a loss to the public } \\ \text { profit } & \text { stockmarket } & \text { taxing our absentees } \\ \text { employ } & \text { refinement } & \text { collateral advantage } \\ \text { success } & \text { commodity } & \text { money rewards } \\ \text { value } & \text { manufacture } & \text { foreign fineries } \\ \text { goods } & \text { expensiveness } & \text { gain of eight shillings } \\ \text { project } & \text { per annum } & \text { by the sale of children }\end{array}$

The way he calculated the economic advantages available to the poor, the rich and the Irish society at large further lends credibility to his status as a seasoned business man of his time.

Mathematics

Swift's economic and sociological proposal is well grounded in proper calculation and statistical analysis. His calculations are very exact and this situation lends credibility and realism to his 'proposal'. In the second and third pages of the 'proposal', he tries to concritise his ideas in figures. For example, in the third paragraph of the second page, his worded calculations can be reduced to figures as stated below:
$1,500,000 \quad$ - People
200,000 - Breeders
30,000 - Mothers that cannot maintain their children
170,000
- Breeders remaining death
50, 000 - Death, still-birth and miscarriage
120, $000 \quad$ - Poor children annually born.

On the whole, about 559 words are devoted to calculations and the number represents a significant percentage (about $17.17 \%$ ) of the total number of words in the passage.

\section{Agriculture/Animal Science}

Swift, in his ironic proposal, turned human beings into farm or poultry products. He wrote on human beings as if they were animals. He discussed the various parts of the human body as animal physiology. He believed that "the carcass, the skin... artificially dressed, will make admirable gloves for ladies, and summer boots for fine gentlemen". Apart from mutually inclusive words, there are about one hundred and twenty-eight other words that are particularly relevant to animal science and agriculture. Such words and phrases include: 


$\begin{array}{lll}\text { fat } & \text { fatten } & \text { Black cattle } \\ \text { fish } & \text { nursing } & \text { infact's flesh } \\ \text { deer } & \text { Plump } & \text { Nutritive meat } \\ \text { pigs } & \text { butchers } & \text { Swine's flesh } \\ \text { corn } & \text { Rotting } & \text { mares in faol } \\ \text { sows } & \text { fattest } & \text { Bulk of farmers } \\ \text { suck } & \text { growth } & 20,000 \text { carcasses } \\ \text { Body } & \text { Farming } & \text { ready to farrow }\end{array}$

More than anything else, Swift's use of registers of animal science is very appropriate here since the theme of his discussion is man's inhumanity to man or excessive degradation of man to the level of animals. The situation in Ireland of Swift's time placed man on a level even lower than that of animals. There was oppression and injustice of all sorts, culminating in worthlessness of human lives. The reference or allusion to the animal world in the proposal is not just accidental, rather it is a deliberate and subtle attack on the British overlords dehumanizing the Irish. On a more ironic tone, Swift was satirizing the oppressive policy of the British by exposing the absurd situation with a view to achieving a positive change to a new social order.

Catering (Hotel Management)

Swift's ironic masterpiece appears to have been based on a cannibalistic instinct perhaps unprecedented in human history. In writing his horribly beautiful feasibility studies, he used registers of caterers (hoteliers) advertising their new dainties of every part of the human body so as to get numerous customers. Like a caterer, Swift maintained that a child at a year old would be plump and fat for a good table. He continues:

A child will make two dishes at an entertainment for

friends; and when the family dines alone, the fore or

hind quarter will make a reasonable dish, and, seasoned

with a little pepper or salt, will be very good boiled

on the fourth day, especially in winter (p.5).

Apart from mutually inclusive words, there are about one hundred and thirty-nine words that specifically refer to catering business such as:

\begin{tabular}{ll}
$\begin{array}{l}\text { delicious } \\
\text { nourishing }\end{array}$ & two dishes \\
food & dines \\
stewed & reasonable dish \\
roasted & seasoned with a little salt \\
baked & a profit diet \\
boiled & roasting pigs \\
fricasse/ a ragout & disagreeable taste \\
fat for a good table & dainty \\
skillful cook & taverns \\
\hline
\end{tabular}

Relevance of Communication Accommodation Theory to Register Analysis in A Modest Proposal.

From the foregoing, it is evident that Swift was able to communicatively adjust to various registers so as to effectively 'carry' his audience along in order to convince them to accept his satirical proposal which indeed is a harsh criticism of the extreme degradation of humanity to the level of animals meant for food. This adjustment is in line with the view of Dragojevic, Gasiorek and Giles (2016) that "in interaction, we adjust and adapt to our fellow speakers. Communicative adjustment is ubiquitous and constitutes a fundamental, and ... necessary part of successful social interaction".

A Modest Proposal can be seen to exemplify various dimensions of communication adjustments propounded by Giles. Firstly, the satirical novel exemplifies the 'upward adjustment' strategy in that the registers in the text belong to a "more prestigious variety of speech" (ibid). Secondly, the registers of the novel demonstrate full adjustment to variations of professions to suit the discourse. Thirdly, due to the multiple registers that are used simultaneously, the text exemplifies multimodal divergence. Fourthly, as a result of the obvious fact that throughout the text, Swift ensured sustained continuous adjustments of registers to depict the appropriate professions he assumed at different stages of the discourse, the text can be said to exemplify the long-term communicative adjustment. The positive chameleonic switch from one register to another is sustained. This is in line with the view of Giles, et al (2016, p.39) that long-term adjustment is the style that "is more sustained and occurs repeatedly over multiple interactions (long term)"(ibid).

\section{Conclusion}

Diverse as the vocabulary items appear to be, they are at the deep structure greatly interrelated since the presence of one is required in the description of the others. Thus, a pamphleteer cannot adequately discuss the current 
issue without making use of related sociological and economic terms. For example, an economist should be interested in mathematics (so as to calculate well), agriculture (since it is part of the economy), politics (since it shapes the pattern of the economy), catering (since it is a business organization), sociology (since economy is essentially a social phenomenon) and pamphleteering (because he needs to keep abreast of latest pieces of information). From this paper, it can be seen that the meaning of any message should be regarded as a spectrum rather than as a set of enclosed cells. Thus, it can be said that the diction through which the message of $A$ Modest Proposal is conveyed is of a band of professions (like pamphleteering, economics, animal science etc) formed by a set of literary lines created by Swift. As indicated in the introduction, one needs to see swift as a seasoned writer of his time who was able to use the registers of the various professions to convince readers of the fact that proper homework had been done before presenting his 'Modest Proposal', and in this connection, it is to be submitted that the use of language to persuade, influence or promote actions is by all means important to literature.

Swift has indeed been able to influence his desired ideas on the audience/readers through a special kind of open communication accommodation theory of language as a means of effective communication. Though the words are familiar, they were skilfully arranged for the best effects by the old Swift, indeed the British Satirist who achieved a profound synchronization of the various registers with the impressive effect of producing a hybrid prose passage that indeed qualifies as "a horrible but masterly piece of irony".

\section{References}

Chartrand, T. L., \& Bargh, J. A. (1999). The chameleon effect: the perception-behaviour link and social interaction. Journal of Personality and Social Psychology, 76(6), 893-910. Doi:10.1037/00223514.76.6.893

Coulthard, M (1977).An introduction to discourse analysis, London: Longman.

Dent, J. (1967).Everyman's encyclopedia, J. M. Dent \& Sons Ltd.

Dragojevic, M, Gasiorek, J and Giles, H (2016). "Accommodative strategies as core of the theory", Chapter 3, pp.36-59, in Communication accommodation theory (online)

Ghadessy, M. (1993). "On the nature of written business communication”. In Ghadessy, M. (ed). Register analysis: theory and practice. London and New York: Printer Publishers.

Giles, H. (2008). Communication accommodation theory. In L. A. Baxter \& D. O. Braithewaite (Eds.), Engaging theories in interpersonal communication: multiple perspectives. (pp. 161-173). Thousand Oaks, CA, US: Sage Publications, Inc.

Gile, H., \& Ogay, T. (2007). Communication accommodation theory. In B. B. Whaley \& W. Samter (Eds), explaining communication: contemporary theories and exemplars (pp. 293-310). Mahwah, NJ: Lawrence Erlbaum.

Gregory, M and Carroll, S. (1978). Language and situation, language varieties and their social context. London: Routledge and Kegan Paul.

Hornby, A. S. (2000).Oxford advanced learners' dictionary of current english, (6 ${ }^{\text {th }}$ Edition), Oxford, Oxford University Press.

https://www.poetryfoundation.org>poets

Muir, K. Johnson, A. Cotterill, R.\& Dewdney,N. (2015). Characterizing the linguistic chameleon. (Online).

Malmakjaer, K. (ed.) (2002). The linguistics encyclopedia. London and New York: Routledge.

Osisanwo, W. (2005). Introduction to discourse analysis and pragmatics. Lagos: Femolus - Fetop Publishers.

Swift, J. (1729): A modest proposal, Gutenberg EBook \#1080, July 27, 2008 (Online)

Turnbull, J. (2015): Oxford advanced learner's dictionary, international student's edition. Oxford, Oxford University Press. 